Научная статья

УДК 34:616-02

DOI 10.18101/2658-4409-2021-2-4-9

\title{
О НЕОБХОДИМОСТИ ПРАВОВОЙ ОПРЕДЕЛЕННОСТИ ПОНЯТИЯ «ЯТРОГЕНИЯ»
}

(C) Тимофеев Игорь Владимирович

доктор медицинских наук, профессор, заместитель председателя Уставного суда Санкт-Петербурга, Военно-медицинская академия имени С. М. Кирова

Министерства обороны Российской Федерации

Россия, 194044, г. Санкт-Петербург, ул. Академика Лебедева, 6

igortimofeev58@jmail.com

\begin{abstract}
Аннотация. При рассмотрении так называемых медицинских дел нередко возникают вопросы о содержании недостатков медицинской помощи и их влиянии на исход заболевания (травмы, отравления), что может быть использовано для юридической оценки действий (бездействия) медицинского работника. В связи с этим для одинакового правопонимания предлагают юридически легитимизировать понятия «ятрогения» и «ятрогенная патология».

В статье обсуждается необходимость правовой формализации понятий «ятрогения», «ятрогенная патология». Автором предложены дефиниции этих понятий, которые могут быть использованы законодателем для процесса совершенствования правового, нормативного регулирования медицинской помощи в России.

Ключевые слова: конституционный принцип юридического равенства, правовая неопределенность, ответственность медицинских рабртников, недостатки медицинской помощи, «ятрогения», «ятрогенная патология»
\end{abstract}

\section{Для цитирования}

Тимофеев И. В. О необходимости правовой определенности понятия «ятрогения» // Вестник Бурятского государственного университета. Юриспруденция. 2021. Вып. 2. C. 4-9.

В медицинской и юридической литературе достаточно часто встречается термин «ятрогения», образованный от сочетания слов iatros (от греч. - врач) и genes (от греч. - происхождение). В буквальном герменевтическом смысле это определение не должно включать случаи, в которых медицинская помощь оказывалась средним медицинским персоналом. Тем не менее в медицинской и правоприменительной практике данный термин применяется очень широко и в значительной части для оценки негативных последствий медицинской помощи независимо от уровня образования медицинского работника.

В нашей стране профессор В. В. Некачалов [1], основываясь на анализе летальных исходов, наступивших во время и после медицинских вмешательств, предложил выделять ятрогении трех категорий:

- ятрогения 1-й категории - заболевания, патологические процессы, необычные смертельные реакции, обусловленные неадекватными, ошибочными 
или неправильными медицинскими воздействиями, явившимися непосредственной причиной летального исхода;

- ятрогения 2-й категории - заболевания, патологические процессы, реакции и осложнения, обусловленные медицинскими воздействиями, проведенными по обоснованным показаниям и выполненные правильно;

- ятрогения 3-й категории - заболевания, патологические процессы, реакции, не имеющие патогенетической связи с основным заболеванием или его осложнением и не играющие какой-либо существенной роли в общей танатологической оценке случая.

Как свидетельствует юридическая практика, при рассмотрении так называемых медицинских дел нередко возникают вопросы о содержании недостатков медицинской помощи и их влиянии на исход заболевания (травмы, отравления), что может быть использовано для юридической оценки действий (бездействия) медицинского работника. В этой связи с частой периодичностью и медицинские специалисты, и юристы для одинакового правопонимания предлагают юридически легитимизировать понятие «ятрогения» и «ятрогенная патология».

Правовые основы и культура отношений, включающие права, обязанности и ответственность медицинского работника, пациента и правоохранителей, во многом базируются на соблюдении принципа юридического равенства, диктуют необходимость формальной определенности понятийного аппарата, точности, ясности, недвусмысленности правовых норм и их согласованности в системе действующего правового регулирования.

Как следует из статей 1 (часть 1), 6 (часть 2), 17 (часть 3) и 19 (части 1 и 2) Конституции Российской Федерации и основанных на них правовых позиций Конституционного Суда Российской Федерации, принцип юридического равенства диктует необходимость формальной определенности, точности, ясности, недвусмысленности правовых норм и их согласованности в системе действующего правового регулирования, поскольку юридическое равенство может быть обеспечено лишь при условии единообразного понимания и толкования правовой нормы ${ }^{1}$.

Конституционный Суд Российской Федерации неоднократно подчеркивал, что гарантированные Конституцией Российской Федерации равенство всех перед законом и судом, а также равноправие могут быть обеспечены лишь при условии единообразного понимания и толкования нормы всеми правоприменителями; нарушение принципа формальной определенности норм, напротив, допускает неограниченное усмотрение в процессе правоприменения и неизбежно ведет к произволу, а значит - к нарушению принципа равенства при осуществлении конституционных прав и свобод, верховенства Конституции Российской Федерации и закона².

В настоящее время на законодательном уровне, а также в подзаконных правовых актах понятие «ятрогения» не формализовано. Тем не менее понятие «ятрогенное преступление» активно используется Следственным комитетом Российской Федерации при рассмотрении дел, в которых в той или иной мере расследуются события, связанные с медицинской деятельностью.

1 Постановление Конституционного Суда РФ от 21.01.2019 № 6-П. Текст : непосредственный. 2 Постановление Конституционного Суда РФ от 27.11.2008 № 11-П; Постановление Конституционного Суда РФ от 25.04.2018 № 17-П. Текст : непосредственный. 
В Порядке проведения судебно-медицинской экспертизы и установления причинно-следственных связей по факту неоказания или ненадлежащего оказания медицинской помощи от 21 июня 2017 г. ${ }^{1}$ (далее - Порядок СМЭ) указывается, что, несмотря на отсутствие в уголовном и гражданском законодательстве Российской Федерации понятий «ятрогенные преступления» и «гражданско-правовые последствия ятрогенных воздействий», ятрогения - это любые нежелательные или неблагоприятные последствия профилактических, диагностических или лечебных вмешательств либо процедур, которые приводят к нарушениям функций организма, ограничению привычной деятельности, инвалидизации и смерти; осложнения медицинских мероприятий, развившиеся в результате как ошибочных, так и правильных действий или бездействий врача. При этом предлагается различать понятия «неоказание медицинским работником медицинской помощи пациенту» и «бездействие медицинского работника при оказании медицинской помощи». Согласно Порядку СМЭ, бездействие - более широкое понятие и включает в себя:

1) «полное» неоказание медицинской помощи пациенту, то есть собственно «неоказание медицинской помощи»;

2) «частичное» неоказание («неполное оказание») медицинской помощи, то есть действие не в соответствии с общепринятыми порядками оказания медицинской помощи и стандартами медицинской помощи, утвержденными Министерством здравоохранения Российской Федерации, клиническими рекомендациями (протоколами лечения) по вопросам оказания медицинской помощи, разработанными и утвержденными медицинскими профессиональными некоммерческими организациями.

По нашему мнению, целесообразно выделение двух аспектов проблемы ятрогений: организационно-медицинского и юридического. Первый аспект связан с выявлением и анализом дефектов (недостатков) медицинской помощи и их причин, а также оценкой влияния дефекта на исход. Второй аспект реализуется при формулировке диагноза и ответов на вопросы, поставленные надзирающими и судебно-следственными органами.

Зачастую термин «ятрогения» распространяют на само действие (бездействие) при медицинской помощи. При этом к уже известным ятрогениям, связанным с неквалифицированным действием медицинского работника, по нашему мнению, целесообразно также относить случаи, когда медицинская помощь не была оказана в силу недиагностированного или поздно (несвоевременно) диагностированного основного заболевания, его осложнений или осложнений от медицинских вмешательств, которые обусловили причинение вреда здоровью или наступление смерти пациента. С нашей точки зрения, недиагностирование (позднее диагностирование) известного (не редкого) смертельного осложнения в условиях стационара, где имеется необходимое для этого оборудование, также должно относиться к неквалифицированному действию (бездействию) медицинского работника. Это положение принимается далеко не всеми врачами.

\footnotetext{
${ }^{1}$ Порядок проведения судебно-медицинской экспертизы и установления причинноследственных связей по факту неоказания или ненадлежащего оказания медицинской помощи: методические рекомендации (утв. ФГБУ “РЦСМЭ” Минздрава России 21.06.2017) // СПС «КонсультантПлюс». Текст : непосредственный.
} 
Так, в Сборнике нормативно-методических документов по вопросам патологоанатомических (патоморфологических) исследований, со ссылкой на МКБ-10 (1989 г.), «ятрогения - групповое понятие, объединяющее все разнообразие неблагоприятных последствий (нозологические формы, синдромы, патологические процессы) любых медицинских воздействий на больного, независимо от правильности их исполнения. По своей сущности ятрогении являются вариантом дефектов оказания медицинской помощи» [2]. И далее в пункте 1.2 сборника указано: «К ятрогениям следует относить только те патологические процессы, которые возникли как "результат действия" - медицинских мероприятий, а не запоздалого действия или бездействия медицинского персонала, что может быть врачебной ошибкой, но не ятрогенией» [Там же].

На первый взгляд, авторы сборника, логично разделив все дефекты медицинской помощи, выделили часть этих дефектов, назвав их «дефектами оказания медицинской помощи» и тем самым исключив дефекты, связанные с неоказанием медицинской помощи. Но при этом говорить, что ятрогения - только «результат действия», значит признавать и тавтологически называть дефект медицинской помощи ятрогенией.

Как нам представляется, под ятрогенией необходимо понимать неквалифииированное (непоказанное и/или неправильное) действие или бездействие медииинского работника в случаях, когда этот проиесс негативно повлиял на исход (привел к причинению вреда здоровью или наступлению летального исхода). Таким образом, в правовом и медико-организационном смысле ятрогения является последствием дефекта медицинской помощи, как действия, так и доказанного запоздалого действия или бездействия, повлекшего наступление неблагополучного исхода (вред здоровью или наступление смерти), имеющего причинноследственную связь с причинением медицинским работником вреда здоровью или смертью пациента. При этом, выделяя из дефектов медицинской помощи ятрогению, мы вводим ее квалифицирующий признак - негативное влияние на исход, то есть ятрогения - это последствие дефекта медицинской помощи, негативно повлиявшего на исход заболевания (травмы, отравления).

Исходя не только из синтаксического значения термина, но и из юридической логики понятия «деяния» (как действия, так и бездействия), по нашему мнению, $\kappa$ ятрогенной патологии следует относить патологические процессы, которые обусловлены дефектами медичинской помощи и повлияли на негативный исход заболевания. В этой связи те патологические последствия, которые могут возникнуть вследствие ятрогении, предлагается объединить в термине «ятрогенная патология».

Второй аспект проблемы, который реализуется при формулировке диагноза, связан с месторасположением ятрогении (ятрогенной патологии) в его рубриках (основное заболевание, осложнение основного заболевания или сопутствующее заболевание).

Интеграция данных из одной области знаний (медицины) в другую (юриспруденцию) сложна не столько из-за трудности терминологического перевода, сколько из-за разного образа мышления специалистов. Но кропотливая работа с использованием принципов логики, объективности, разумности, добра и справедливости 
должна в итоге сделать адекватным применение и оценку знаний специалистов из одной и другой сфер.

Еще в 1999 г. мы указывали на то, что отсутствие общепринятой (медицинской и юридической) классификации осложнений диагностики и лечения, дефектов медицинской помощи, определения несчастных случаев и ятрогенных патологий затрудняет проведение организационного и юридического анализа медицинских проблем [3]. Это же является реальным тормозом развития отечественного здравоохранения на пути улучшения КМП. В 2001, 2002, 2017, 2020 гг. с предложениями, направленными на совершенствование правового регулирования в целях улучшения лечебно-диагностического и экспертного процесса, мы обращались к медицинскому и юридическому сообществу [4-7]. Надеемся, что в том числе и настоящая статья подтолкнет как законодателей, так правоприменителей к процессу совершенствования правового, нормативного регулирования медицинской помощи в России.

\section{Литература}

1. Некачалов В. В. О ятрогенной патологии (по секционным материалам Ленинграда за 1988 г. // Архив патологии. 1990. Т. 52, вып. 11. С. 14-17. Текст : непосредственный.

Ятрогении (патологии диагностики и лечения) / М. А. Пальцев [и др.] // Система добровольной сертификации процессов выполнения патоморфологических (патологоанатомических) исследований и патологоанатомических услуг в здравоохранении: сборник нормативно-методических документов по вопросам патологоанатомических (патоморфологических) исследований / под редакцией Р. У. Хабриева, М. А. Пальцева. Москва, 2007. Вып. 1 С. 355-382. Текст : непосредственный.

2. Тимофеев И. В. Патология лечения (руководство для врачей) / под редакцией Ю. Н. Шанина. Санкт-Петербург : Северо-запад, 1999. 656 с. Текст : непосредственный.

3. Тимофеев И. В. Правовая регламентация врачебных экспертиз (глава в руководстве для врачей) // Правоведение. Москва : ГЭОТАР-Мед, 2001. С. 127-171. Текст : непосредственный.

4. Тимофеев И. В., Леонтьев О. В. Медицинская ошибка. Медикоорганизационные и правовые аспекты. Санкт-Петербург : ДНК, 2002. 80 с. Текст : непосредственный.

5. Тимофеев И. В. Право и медицина: конституционно-правовые, организационные вопросы доступности и качества медицинской помощи : учебное пособие для врачей и юристов. Санкт-Петербург : ДНК, 2017. 448 с. Текст : непосредственный.

6. Тимофеев И. В. Медицинская помощь: конституционно-правовые, организационные и деонтологические аспекты. Санкт-Петербург : ДНК, 2020. 544 с. Текст : непосредственный.

Статья поступила в редакичию 15.04.2021; одобрена после рецензирования 17.05.2021; принята к публикации 22.06.2021. 


\title{
ON THE NEED FOR LEGAL DEFINITION OF THE CONCEPT «IATROGENESIS»
}

\author{
Igor $V$. Timofeev \\ Dr. Sci. (Medicine), Prof., \\ Deputy Chief Judge of St. Petersburg Statutory Court, \\ Kirov Military Medical Academy \\ under the Ministry of Defense of the Russian Federation \\ 6 Akademika Lebedeva St., St. Petersburg 194044, Russia \\ igortimofeev58@jmail.com
}

Abstract. When considering so-called medical cases, questions about the content of deficiencies in medical care and their impact on the outcome of the disease (injury, intoxication) often arise. This information can be used for a legal assessment of the actions (inaction) of a medical worker. In this regard, it is proposed to legitimize the concepts «iatrogenic» and «iatrogenic pathology» for their equal legal understanding.

The article discusses the need for legal perfection of the concepts of «iatrogenesis», «iatrogenic pathology». We have proposed the definitions of these concepts, which can be used by the legislator for improving legal regulation of medical care in Russia.

Keywords:constitutional principle of legal equality, legal uncertainty, responsibility of medical professionals, deficiencies in medical care «iatrogenesis», «iatrogenic pathology», legal uncertainty

\section{For citation}

Timofeev I. V. On the Need for Legal Definition of the Concept «Iatrogenesis». Bulletin of Buryat State University. Law. 2021; 2: 4-9 (In Russ.).

The article was submitted 15.04.2021; approved after reviewing 17.05.2021; accepted for publication 22.06.2021. 